\title{
Influence of mature men way of life on highly intensive physical activity
}

\author{
Pryshva O.B. \\ Kherson State University
}

\begin{abstract}
Purpose:

Highly intensive physical activity is the most effective for men's health protection. In modern life conditions its level is insufficient. It requires organism's appropriate physical activity, which is determined by way of life. Especially important it is before trainings. To study special aspects of different intensity's physical activity; of eating special food and sleeping regime of mature men before their highly intensive physical trainings.

Material: $\quad$ in experiment men $(\mathrm{n}=26$, age - 35-53years), who practice healthy life style and independent physical activity of high intensity, participated. We used bio-register Basis B1. Every day we registered: Peak - physical activity of different intensity; duration and quality of sleep; relative weight of consumed food. Besides, we calculated body mass index and physical condition. The study was conducted during 30 days in winter period. The following results were compared: indicators before not planned physical activity and average-monthly indicators.

Results: $\quad$ Before arbitrary physical functioning we found in men: confident weakening of average intensity (by 9-11\%) and low intensity (by 10\%) physical activity; confident increase of consumed food's relative weight (by 6.82\%), vegetarian food (by 10.64\%) and raw food (by 7.61\%); confident reduction of animal origin food (by 8.7\%). No changes were found in duration and quality of sleep before highly intensive physical functioning.

Conclusions: specific features of mature men's way of life before their not planned highly intensive physical functioning are as follows: reduction of general physical activity; increase of consumed food. These factors facilitate energy accumulation in organism for its realization in highly intensive physical functioning the next day.

Keywords: $\quad$ way of life, physical activity (functioning), eating, sleeps, physical condition, men, mature age.
\end{abstract}

\section{Introduction}

Physical activity (PA) is one of required conditions of healthy full-fledged life. Human modern way of life leaves still less and less space for realization of this important function of organism. From minimal required daily distance mature men walk only half [20, 21]. For cardio-vascular system's (CVS) and general physical condition normalization physical activity of high and moderate intensity is the most effective [7]. But mature man's organism is not always ready for such intensity. In researches [2, 3] we found dependence of men's highly intensive physical activity (HIPA) on CVS current condition. It served as indicator of human general physical condition at the beginning of training day, which, probably, is conditioned by life style the day before. The most substantial physiological factors, influencing on human physical condition, are: physical functioning of other intensity, eating and sleep [19], on which physical condition and ability of healthy man to practice HIPA depend. Traditionally components of mature men's life style are studied for prevention from widely spread age diseases. Recent years the quantity of works devoted to influences of life style components on human physical condition has been increasing $[8,12,18]$. In other work it was proved [17], that optimal HIPA planning for men is realized in days of increase of CVS tension (within standards) in respect to previous day. Other studies also

(c) Pryshva O.B., 2017

doi:10.15561/18189172.2017.0305 prove dependence of physical condition on PA, immobile way of life, rest regime [13, 16, 19].

Eating regime and consumed food products are the most significant factors in formation of human physical condition [12]. Besides, there is inter-dependence between eating and physical activity [6]. The author found influence of some food products on men's PA [18]. Besides, it was found that some food products influence on human physical condition and improve sport results [5].

Sleep plays important role in control of organism's metabolism. Sleep quality is directly connected with human life quality [4]. As per the data of many researches sleep of adult person shall take from 7 to 8 hours a day. Sleep deficiency reduces PA level. At the same time sleep sufficiency facilitates increase of PA [8]. Night sleep can be regarded in day and night format as a source of energy accumulation before active phase. Besides, it can be regarded as result of day active phase. Organism shall have enough energy for next day. In case of incomplete sleep organism can start the day with energy deficit. Human organism has to compensate this deficit from other sources and one of them can be excessive eating [9]. Besides, certain dependences between the set of consumed food products, their quality and sleep duration were determined [11, 15], as well as between PA kinds and sleep quality [10].

Hypothesis: it was assumed that specific features of life style before HIPA will help to understand of stimuli emersion for HIPA in men and simulate these specificities 
for increase PA trainings' quantity.

Purpose: to study special aspects of different intensity physical activity; eating special food; sleeping regime of mature men before their highly intensive physical trainings.

\section{Material and methods}

Participants: in experiment men $(n=26$, age 35-53years), who practice healthy life style and independent physical activity of high intensity in the forms of health related run, swimming and fitness, participated. All participants were instructed at medical-biological disciplines' department of Kherson state university. In the research bio-registers BASIS B1, BASIS PEAK were used.

Organization of the research: the studies were fulfilled at the south of Ukraine in winter period 2015. During 30 days we studied special aspects of men's life style before not planned HIPA trainings and compared them with everyday indicators. The participants practiced usual life style and every day registered their physical condition indicators in the morning: body weight, heart beats rate (HBR) blood pressure (BP); general weight of consumed food products as per their origin: animal, vegetarian, raw. During day and night bio-registers registered physical activity: high (85\% from maximal admissible for the age- $145 \mathrm{bpm}$ and higher), average (from $70 \%$ to $84 \%$, $121-145 \mathrm{bpm}$ ) ad low (from 50\% to $69 \%$, - 88-120 bpm). We noted: daily PA - as quantity of steps (steps/day) in each zone; PA time (min/day), except low intensity; PA intensity (steps/min). Besides, we registered sleep duration (min) and its quality in percents (\%) per day and in night time.

According to experimental requirements HIPA trainings shall not be planned beforehand. Men practiced HIPA only if individual wish appeared.

Statistical analysis: basing on daily reports of the participants and bio-registers' indicators we calculated: body mass index (BMI) $\left(\mathrm{kg} / \mathrm{m}^{2}\right)$; index of cardio-vascular system's adaptation potential by Bayevskiy (API) was calculated in absolute units (a.un.) [1]; HBR during HIPA trainings. For general physiological characteristic of the participants PA results were calculated every week. For comparison of days before HIPA with average monthly (without days with HIPA) results were rendered in day/ night format.

Percents were calculated by formula

$$
x=(b-a): a * 100 \%
$$

where, $x$ - is percentage value; $a$ - previous indicator and $b$ - next indicator of compared pair of numbers.

Statistical processing was fulfilled with methods of non parametrical statistics as far as results did not correspond to normal distribution. We found the following: 95\% inter-quartile range (IR), median $(\mathrm{Me})$. Comparison of indicators between days was fulfilled with the help of Wilcoxon's criterion with level of confidence $(p=0.05)$. EXCEL and Statgraphics16 programs were applied.

\section{Results}

Physiological characteristic of mature men (see table 1) was based on BMI values (which was in average $27.83 \mathrm{~kg}$ / $\mathrm{m}^{2}$ ) and API (average indicator - 1.61a.un.). Such data show normal condition of men's cardio-vascular systems. Per one week men's HIPA was 2.1 times with volume of 3604.71st/week and spent time - $21.53 \mathrm{~min}$. The tested average HBR during HIPA trainings was $143.31 \mathrm{bpm}$. It characterizes its high intensity.

Comparative of average and low intensity daily PA before HIPA trainings showed significant distinctions (see table 2). Quantity of steps in average intensity PA before HIPA was 3072.42 st/day. It is by $9.15 \%$ confidently less than everyday indicators (3353.50 st/day). Quantity of low intensity PA steps before training was 5960.23st/day. It is by $10.41 \%$ confidently less than everyday quantity (6682.19 st/day). Average intensity PA time before HIPA was $30.46 \mathrm{~min} /$ day. It is by $11.13 \%$ confidently less than everyday indicators (33.85 min.). Day intensity of average PA had no substantial distinctions: only $1.79 \%$ with quantity of $80.87 \mathrm{st} / \mathrm{min}$ before HIPA and $82.32 \mathrm{st} /$ min. everyday. On the contrary, low daily intensity before HIPA was $5.72 \mathrm{st} / \mathrm{min}$. and everyday - $6.31 \mathrm{st}$.min. It is by $10.4 \%$ confidently less.

Comparison of consumed food products before HIPA and everyday showed significant distinctions by all indicators (see table 3). Relative weight of consumed food before HIPA was $30.65 \mathrm{~g}$. It is by $6.82 \%$ more than every day (28.65g). Relative weight of animal origin food before HIPA was $6.45 \mathrm{~g}$. It is by $8.7 \%$ less than everyday consumption (7.01 g). Relative weight of vegetation origin food before HIPA was $2128 \mathrm{~g}$. It is by $10.64 \%$ more than everyday (19.53g.). Relative weight of raw food before HIPA was $16.26 \mathrm{~g}$. It is by $7.61 \%$ more than everyday consumption (15.02 g).

Rest regime was studied by indicators of day/night sleep, night sleep and their quality (see table 4). We did not find confidence differences between sleeping before

Table 1. Physiological indicators of mature men, who practice healthy life style $(n=26)$

\begin{tabular}{ll}
\hline № $\quad$ Indicators & Me (95\%IR) \\
\hline BMI $\left(\mathrm{kg} / \mathrm{m}^{2}\right)$ & $27.83(25.08 ; 30.58)$ \\
API (a.un.) & $1.61(1.53 ; 1.69)$ \\
Quantity of HIPA per week (times/week) & $2.1(1.08: 3.12)$ \\
HIPA (steps/week) & $3604.71(2816.43 ; 4392.99)$ \\
HIPA time (min/week) & $21.53(17.34 ; 25.72)$ \\
HBR during HIPA (bpm) & $143.31(134.28 ; 152.34)$ \\
\hline
\end{tabular}


Table 2. Comparison of men's average and low physical activity before HIPA with every day indicators

\begin{tabular}{|c|c|c|c|c|c|}
\hline № & Indicator & $\begin{array}{l}\text { Before HIPA }(n=208) \\
M e \\
(95 \% \text { IR) }\end{array}$ & $\begin{array}{l}\text { Everyday indicator } \\
(\mathrm{n}=780) \\
\text { Me } \\
(95 \% \text { IR) }\end{array}$ & $\begin{array}{l}\text { Difference } \\
(\%)\end{array}$ & $\begin{array}{l}W \\
(p)\end{array}$ \\
\hline & $\begin{array}{l}\text { Average intensity PA } \\
\text { (steps/day) }\end{array}$ & $\begin{array}{l}3072.42 \\
(2451.27 ; 3693.57)\end{array}$ & $\begin{array}{l}3353.50 \\
(2248.03 ; 4458.97)\end{array}$ & 9.15 & $\begin{array}{l}62476 \\
<0.05\end{array}$ \\
\hline & $\begin{array}{l}\text { Low intensity PA (steps/ } \\
\text { day) }\end{array}$ & $\begin{array}{l}2116.23 \\
(1246.29 ; 2986.17)\end{array}$ & $\begin{array}{l}2336.54 \\
(1372.34 ; 3300.74)\end{array}$ & 10.41 & $\begin{array}{l}61334 \\
<0.05\end{array}$ \\
\hline & $\begin{array}{l}\text { Average intensity PA time } \\
\text { (minutes/day) }\end{array}$ & $\begin{array}{l}30.46 \\
(21.90 ; 39.02)\end{array}$ & $\begin{array}{l}33.85 \\
(20.37 ; 47.33)\end{array}$ & 11.13 & $\begin{array}{l}65440 \\
<0.05\end{array}$ \\
\hline & $\begin{array}{l}\text { Intensity of average PA } \\
\text { (steps/min) }\end{array}$ & $\begin{array}{l}80.87 \\
(71.04 ; 90.7)\end{array}$ & $\begin{array}{l}82.32 \\
(70.98 ; 93.67)\end{array}$ & 1.79 & $\begin{array}{l}21097 \\
>0.05\end{array}$ \\
\hline & $\begin{array}{l}\text { Intensity of low PA (steps/ } \\
\text { min) }\end{array}$ & $\begin{array}{l}5.72 \\
(3.51 ; 7.93)\end{array}$ & $\begin{array}{l}6.31 \\
(2.75 ; 9.87)\end{array}$ & 10.4 & $\begin{array}{l}63849 \\
<0.05\end{array}$ \\
\hline
\end{tabular}

Table 3. Comparison of the consumed by men food products before highly intensive physical activity and every day

\begin{tabular}{|c|c|c|c|c|c|}
\hline № & Indicator & $\begin{array}{l}\text { Before HIPA } \\
(n=208) \\
M e \\
(95 \% \text { IR) }\end{array}$ & $\begin{array}{l}\text { Every day } \\
(\mathrm{n}=780) \\
M e \\
(95 \% \text { IR) }\end{array}$ & $\begin{array}{l}\text { Difference } \\
\text { (\%) }\end{array}$ & $\begin{array}{l}W \\
(p)\end{array}$ \\
\hline & $\begin{array}{l}\text { Relative weight of consumed food } \\
(\mathrm{g} / \mathrm{kg})\end{array}$ & $\begin{array}{l}30.65 \\
(19.26 ; 42.04)\end{array}$ & $\begin{array}{l}28.56 \\
(14.48 ; 42.64)\end{array}$ & -6.82 & $\begin{array}{l}57612 \\
<0.05\end{array}$ \\
\hline & $\begin{array}{l}\text { Relative weight of animal origin } \\
\text { consumed food }(\mathrm{g} / \mathrm{kg})\end{array}$ & $\begin{array}{l}6.45 \\
(3.29 ; 9.61)\end{array}$ & $\begin{array}{l}7.01 \\
(4.71 ; 9.31)\end{array}$ & 8.7 & $\begin{array}{l}60145 \\
<0.05\end{array}$ \\
\hline & $\begin{array}{l}\text { Relative weight of consumed } \\
\text { vegetarian food }(\mathrm{g} / \mathrm{kg})\end{array}$ & $\begin{array}{l}21.28 \\
(9.15 ; 33.41)\end{array}$ & $\begin{array}{l}19.53 \\
(7.88 ; 31.18)\end{array}$ & -10.64 & $\begin{array}{l}62412 \\
<0.05\end{array}$ \\
\hline & $\begin{array}{l}\text { Relative weight of consumed } \\
\text { vegetarian raw food }(\mathrm{g} / \mathrm{kg})\end{array}$ & $\begin{array}{l}16,26 \\
(6.38 ; 26.14)\end{array}$ & $\begin{array}{l}15.02 \\
(4.62 ; 25.42)\end{array}$ & -7.61 & $\begin{array}{l}58472 \\
<0.05\end{array}$ \\
\hline
\end{tabular}

Table 4. Comparison of sleeping regimes before highly intensive physical activity and every day

\begin{tabular}{|c|c|c|c|c|c|}
\hline № & Indicator & $\begin{array}{l}\text { Before HIPA } \\
(\mathrm{n}=208) \\
M e \\
(95 \% \text { IR) }\end{array}$ & $\begin{array}{l}\text { Every day } \\
(\mathrm{n}=780) \\
\text { Me } \\
(95 \% \text { IR) }\end{array}$ & $\begin{array}{l}\text { Difference } \\
(\%)\end{array}$ & $\begin{array}{l}W \\
\text { (p) }\end{array}$ \\
\hline & Day/night sleep (min) & $\begin{array}{l}505.24 \\
(432.48 .578)\end{array}$ & $\begin{array}{l}497.57 \\
(425.34 ; 569.8)\end{array}$ & -1.52 & $\begin{array}{l}32986 \\
>0.05\end{array}$ \\
\hline & Quality of day/night sleep (\%) & $\begin{array}{l}81.37 \\
(76.14 ; 86.6)\end{array}$ & $\begin{array}{l}79.07 \\
(71.67 ; 86.47)\end{array}$ & -2.83 & $\begin{array}{l}37854 \\
>0.05\end{array}$ \\
\hline & Night sleep (min) & $\begin{array}{l}450.78 \\
(392.26 ; 509.3)\end{array}$ & $\begin{array}{l}457.96 \\
(392.84 ; 523.08)\end{array}$ & 1.59 & $\begin{array}{l}29351 \\
>0.05\end{array}$ \\
\hline & Quality of night sleep (\%) & $\begin{array}{l}79.76 \\
(74.23 ; 85.29)\end{array}$ & $\begin{array}{l}78.94 \\
(72.51 ; 85.37)\end{array}$ & -1.02 & $\begin{array}{l}31457 \\
>0.05\end{array}$ \\
\hline
\end{tabular}

HIPA and in everyday regime. Before HIPA sleep duration was 505.24 minutes, with difference of $1.52 \%$, comparing with everyday sleep (497.57 minutes). Sleep quality was 81.37\% before HIPA and 79.07 in every day regime (difference - 2.83\%). Night sleep duration was 450.78 minutes before HIPA and 457.96 everyday (difference $1.59 \%$ ). Night sleep quality before HIPA was $79.76 \%$, and every day - 78.94\% (difference - 1.02\%).

\section{Discussion}

Analysis of men’s physical condition supplemented information $[10,12]$ about tendency to excessive weight of men and insufficient HIPA level [9, 114]. In our study BMI of men exceeds standard by $2.83 \mathrm{~kg} / \mathrm{m}^{2}$.

With it, cardio-vascular system corresponds to API requirements (1.80 a.un.) [1]. The daily quantity o walked steps witnesses about mainly immobile lie style o most o urban population. The quantity of average intensity steps corresponds to standard indicators (3000 st/day) [21]. Weekly PA of high intensity is insufficient to meet the recommendations of World health protection organization and other researches [14]. This indicator is 1 minute/day 
more than average statistical [21]. The tested HBR and quantity of steps per minute during HIPA trainings prove their high intensity for this age category of men [20].

Comparative analysis of men's PA proved for the first time that before HIPA physical activity of other intensity was confidently lower: by quantity of daily steps; by PA time; by quantity of steps per minute in zone of low intensity. Such PA reduction witnesses about accumulation of energy before HIPA. Exclusion was only quantity of steps per minute in PA of average intensity. It can be regarded as factor of men's individuality, which does not depend on energy accumulation or consumption.

Eating is the most substantial factor of life style. For the first time we proved that consumed per day relative weight of food products in total, vegetarian food and vegetarian raw food products was confidently higher before HIPA than in other days. Relative weight of animal origin food was confidently less. Total quantity and qualitative content of the consumed food products, prevailing carbohydrates facilitate accumulation of energy in organism before HIPA. Confident reduction of animal origin food is conditioned by reduction of energy consuming for organism kind of food [5].

Sleep is a result of life style in previous day. Sleep duration before HIPA and everyday corresponds to age standards [8]. There were no distinctions in duration and quality of sleep with confident PA reduction and increase of food consumption. It does not confirm the data of other works $[10,15]$ about reduction of sleep duration with increase of consumed food. Increase of consumed food is a result of lack of sleeping or food quality is under question. In our research permanence of sleep duration and quality is explained by lower PA, which compensates sleep duration's reduction from the point of organism's energetic balance.

General tendency of mature men life activity's physiological components is directed to accumulation of organism's energy reserves in day preceding HIPA. It is also explained by CVS activation the next day [3, 17], when API confidently grows. Such energy accumulation results in natural demand in HIPA.

\section{Conclusions}

The research found increase of body weight and insufficient physical activity of mature men, who have no chronic diseases. We registered certain distinctions before not planned HIPA trainings, comparing with everyday regime. General physical activity, its volume and intensity were confidently lower. Relative weight of consumed food, vegetarian food and raw vegetarian food was confidently higher. Relative weight of consumed animal origin food was confidently less. There were found no confident distinctions in duration and quality of day/ night and night sleep. The determined special features of men's life style are directed at energy accumulation in organism for its further realization in highly intensive physical activity the next day.

\section{Conflict of interests}

The author declares that there is no conflict of interests.

\section{References}

1. Baevskij RM, Berseneva AP. Donozologicheskaia diagnostika v ocenke sostoianiia zdorov’ia [Pre-nosological diagnostic in health assessment]. In: Valeologiia: diagnostika, sredstva i praktika obespecheniia zdorov'ia [Valueology: diagnostic, means and practice of health protection], Sankt Petersburg: Science; 1993. P. 33-48. (in Russian)

2. Pryshva OB. Vpliv stanu sercevo-sudinnoi sistemi cholovikiv zrilogo viku na ikhniu fizichnu aktivnist' $\mathrm{v}$ osinnij period [Influence of mature men's cardio-vascular system's condition on their physical activity in Autumn]. Fizichne vikhovannia, sport $i$ kul'tura zdorov'ia $u$ suchasnomu suspil'stvi, 2016;2 (34): 38-45. (in Ukrainian)

3. Pryshva OB. Peculiar features of men physical condition in planning highly intensive physical loads in winter period. Pedagogics, psychology, medical-biological problems of physical training and sports, 2016; 20(2): 46-51. doi:10.15561/18189172.2016.0207

4. Araújo MFM, Lima ACS, Alencar AMPG, Thiago MA, Fragoso LVC, Damasceno MC. Avaliação da qualidade do sono de estudantes Universitários de Fortaleza [Sleep quality of university students from Fortaleza]. Texto Contexto Enferm, 2013;22(2): 352-60. (in Portugal)

5. Baker LB, Nuccio RP, Jeukendrup AE. Acute effects of dietary constituents on motor skill and cognitive performance in athletes. Nutr Rev. 2014;72:790-802.

6. Blundell JE, Gibbons C, Caudwell P, Finlayson G, Hopkins M. Appetite control and energy balance: impact of exercise. Obes Rev. 2015;16:67-76.
7. Carson V, Tremblay MS, Chaput JP, Chastin SFM. Associations between sleep duration, sedentary time, physical activity and health indicators among Canadian children and youth using compositional analyses. Appl. Physiol. Nutr. Metab. 2016;41:10-15. doi:10.1139/apnm2016-0026

8. Chaput JP, Dutil C. Lack of sleep as a contributor to obesity in adolescents: impacts on eating and activity behaviors. International Journal of Behavioral Nutrition and Physical Activity, 2016;13:103-110. doi:10.1186/s12966-016-04280 .

9. Chaput JP. Is sleep deprivation a contributor to obesity in children? Eat Weight Disord. 2016;21:5-11.

10. Chennaoui M, Arnal PJ, Sauvet F, Léger D. Sleep and exercise: a reciprocal issue? Sleep Med Rev. 2015;20:5972.

11. Crispim CA, Zimberg IZ, dos Reis BG, Diniz RM, Tufik $\mathrm{S}$, de Mello MT. Relationship between food intake and sleep pattern in healthy individuals. J Clin Sleep Med 2011;7(6):659-664.

12. Dhurandhar EJ, Dawson J, Alcorn A, Larsen LH, Thomas EA, Cardel M, Bourland AC, Astrup A, St-Onge MP, Hill JO. The effectiveness of breakfast recommendations on weight loss: a randomized controlled trial. Am J Clin Nutr. 2014;100(2):507-13. doi:10.3945/ajcn.114.089573

13. Drogomeretsky VV, Kopeikina EN, Kondakov VL, Iermakov SS. Adaptation of Ruffier's test for assessment of heart workability of students with health problems. Pedagogics, psychology, medical-biological problems of physical training and sports, 2017; 21(1): 


\section{4-10. doi:10.15561/18189172.2017.0101}

14. Hallal PC, Andersen LB, Bull FC, Guthold R, Haskell W, Ekelund U. Global physical activity levels: surveillance progress, pitfalls, and prospects. Lancet. 2012;380(9838):247-257.

15. Peuhkuri K, Sihvola N, Korpela R. Diet promotes sleep duration and quality. Nutr Res. 2012;32:309-19.

16. Podrigalo LV, Iermakov SS, Alekseev AF, Rovnaya OA. Studying of interconnectios of morphological functional indicators of students, who practice martial arts. Physical education of students, 2016; 20(1): 64-70. doi:10.15561/20755279.2016.0109

17. Pryshva O. Physical Condition Markers of Men of Mature Age in High Intensity Physical Activity During the Summer Season. Physical education, sports and health culture in modern society, 2016;1 (33): 69-75.

18. Pryshva O, Tsos A. Interconnection of A Physical Activity of Mature Males with Their Diet. Research Journal of Pharmaceutical, Biological and Chemical Sciences, 2016;7(6):14-20.

19. Tremblay MS, Carson V, Chaput JP, Connor Gorber S, Dinh T, Duggan M. Canadian 24-hour movement guidelines for children and youth: an integration of physical activity, sedentary behaviour, and sleep. Appl Physiol Nutr Metab. 2016;41(3):S311-27.

20. Tudor-Locke C, Craig CL, Aoyagi Y, Bell RC, Croteau KA, De Bourdeaudhuij I. How many steps/day are enough? For older adults and special populations. International Journal of Behavioral Nutrition and Physical Activity. 2011;8(1):80-85. doi:10.1186/1479-5868-8-80

21. Tudor-Locke C, Rowe DA. Using cadence to study freeliving ambulatory behaviour. Sports Med. 2012;42(5):38198.

Information about the author:

Pryshva O.B.; http://orcid.org/0000-0002-3727-5142; ooobc@yahoo.com; Kherson State University; Str. University, 27, Kherson, 73000, Ukraine.

Cite this article as: Pryshva OB. Influence of mature men way of life on highly intensive physical activity. Pedagogics, psychology, medical-biological problems of physical training and sports, 2017;21(3):126-130. doi:10.15561/18189172.2017.0305

The electronic version of this article is the complete one and can be found online at: http://www.sportpedagogy.org.ua/index.php/PPS/issue/archive

This is an Open Access article distributed under the terms of the Creative Commons Attribution License, which permits unrestricted use, distribution, and reproduction in any medium, provided the original work is properly cited (http://creativecommons.org/licenses/by/4.0/deed.en).

Received: 04.02.2017

Accepted: 25.02.2017; Published: 30.04.2017 